University of Wollongong

Research Online

Australian Institute for Innovative Materials -

Papers

Australian Institute for Innovative Materials

$1-1-2016$

\title{
UV cross-linkable graphene/poly(trimethylene carbonate) composites for 3D printing of electrically conductive scaffolds
}

\author{
Sepidar Sayyar \\ University of Wollongong, sepidar@uow.edu.au \\ Miina M. Bjorninen \\ University of Wollongong, miinab@uow.edu.au \\ Suvi P. Haimi \\ University of Helsinki, University of Twente \\ Susanna S. Miettinen \\ University of Tampere \\ Kerry J. Gilmore \\ University of Wollongong, kerryg@uow.edu.au
}

See next page for additional authors

Follow this and additional works at: https://ro.uow.edu.au/aiimpapers

Part of the Engineering Commons, and the Physical Sciences and Mathematics Commons

Research Online is the open access institutional repository for the University of Wollongong. For further information contact the UOW Library: research-pubs@uow.edu.au 


\title{
UV cross-linkable graphene/poly(trimethylene carbonate) composites for 3D printing of electrically conductive scaffolds
}

\author{
Abstract \\ Conductive, flexible graphene/poly(trimethylene carbonate) (PTMC) composites were prepared. Addition \\ of just 3 wt \% graphene to PTMC oligomers functionalized with methacrylate end-groups followed by UV \\ cross-linking resulted in more than $100 \%$ improvement in tensile strength and enhanced electrical \\ conductivity by orders of magnitude without altering the processability of the host material. The addition \\ of graphene also enhanced mesenchymal stem cell (MSC) attachment and proliferation. When electrical \\ stimulation via the composite material was applied, MSC viability was not compromised, and osteogenic \\ markers were upregulated. Using additive fabrication techniques, the material was processed into \\ multilayer 3D scaffolds which supported MSC attachment. These conducting composites with excellent \\ processability and compatibility with MSCs are promising biomaterials to be used as versatile platforms \\ for biomedical applications.

\section{Disciplines} \\ Engineering | Physical Sciences and Mathematics

\section{Publication Details} \\ Sayyar, S., Bjorninen, M., Haimi, S., Miettinen, S., Gilmore, K., Grijpma, D. \& Wallace, G. (2016). UV cross- \\ linkable graphene/poly(trimethylene carbonate) composites for 3D printing of electrically conductive \\ scaffolds. ACS Applied Materials and Interfaces, 8 (46), 31916-31925.
}

\section{Authors}

Sepidar Sayyar, Miina M. Bjorninen, Suvi P. Haimi, Susanna S. Miettinen, Kerry J. Gilmore, Dirk Grijpma, and Gordon G. Wallace 


\section{UV-Crosslinkable Graphene/ poly (trimethylene}

\section{carbonate) Composites for 3D Printing of}

\section{Electrically Conductive Scaffolds}

Sepidar Sayyar ${ }^{\dagger}$, Miina Bjorninen ${ }^{\dagger}$, Suvi Haimi ${ }^{\ddagger}$, Susanna Miettinen", Kerry Gilmore ${ }^{\dagger}$, Dirk Grijpma $^{\S \#}$, Gordon Wallace*广

$\uparrow$ ARC Centre of Excellence for Electromaterials Science (ACES), Intelligent Polymer Research Institute, AIIM Facility, Innovation Campus, University of Wollongong, NSW 2522, Australia

†Department of Oral and Maxillofacial Sciences, Clinicum, University of Helsinki Helsinki, Finland

§MIRA Institute for Biomedical Technology and Technical Medicine, Department of Biomaterials Science and Technology, University of Twente, Enschede, The Netherlands. \|Adult Stem Cell Group, BioMediTech, University of Tampere, Tampere, Finland \#Department of Biomedical Engineering, University of Groningen, University Medical Center Groningen, Groningen, The Netherlands

*E-mail:gwallace@uow.edu.au

Keywords: biomaterials, graphene, PTMC, additive fabrications, mesenchymal stem cells

\section{Abstract}

Conductive, flexible graphene/poly(trimethylene carbonate)(PTMC) composites (PTMCCCG) were prepared. Addition of just $3 \mathrm{wt} . \%$ graphene to PTMC oligomers functionalized with methacrylate end-groups followed by UV-crosslinking results in more than $100 \%$ improvement in tensile strength and enhanced electrical conductivity by orders of magnitude without altering the processability of the host material. The addition of graphene also enhances mesenchymal stem cell (MSC) attachment and proliferation. When electrical stimulation via the composite material is applied, MSC viability is not compromised and osteogenic markers are upregulated. Using additive fabrication techniques, the material is processed into multi-layer 3D scaffolds which supported MSC attachment. These conducting 
composites with excellent processability and compatibility with MSCs are promising biomaterials to be used as versatile platforms for biomedical applications.

\section{INTRODUCTION}

The need for conductive and mechanically durable, biocompatible and degradable materials in tissue engineering has increased as the benefits of electrical stimulation (ES) in tissue regeneration have been recognized. ${ }^{1-3}$ Graphene, a single layer 2D nanomaterial made of $\mathrm{sp}^{2}$ carbon atoms, has recently attracted the attention of researchers due to its extraordinary mechanical, electrical, thermal and optical properties. ${ }^{4-5}$ The properties of graphene and its derivatives that make it attractive for use in tissue engineering are related to the high surface area, electrical conductivity and mechanical properties, such as flexibility and tensile strength, as well as the ease of functionalization. ${ }^{6-7}$ Graphene and its derivatives have been shown to promote and sustain differentiation of anchorage-dependent cells ${ }^{6,8-11}$ including mesenchymal stem cells (MSCs). MSCs are anchorage-dependent multipotent cells that have shown enhanced attachment, proliferation, and differentiation towards several cell types, including osteoblasts and epithelial cells on graphene-based substrates. ${ }^{9,} 12$

Even small loadings of graphene can be used to tailor the properties of biopolymers ${ }^{13-19}$, for instance, addition of less than $5 \%$ graphene can improve the conductivity of biopolymers by up to 13 orders of magnitude. ${ }^{14}$ This allows fabrication of graphene and graphene composite electrodes with versatile functions such as ES of cells that has recently been exploited in neural applications, resulting in improved neurite outgrowth. ${ }^{20-21}$

Despite its advantageous properties for biomedical applications, the biocompatibility and degradation of graphene in physiological environments is not well known and reports on its slight cytotoxicity need to be thoroughly investigated. Yang \& Wan et al. ${ }^{22}$ studied toxicity of graphene sheets functionalized with polyethylene glycol with a size range of 10-30 nm and 
suggested they were gradually cleared from mice by renal and faecal clearance. An injected dose of $20 \mathrm{mg} \mathrm{kg}^{-1}$ did not cause obvious toxicity in the study. Hydrogen peroxidase is reported to take part in the degradation of graphene which could partly facilitate elimination of graphene from the body. ${ }^{23}$ In in vitro studies graphene nanoplatelets incorporated in polylactide (PLA) have shown no cytotoxicity to mouse embryo fibroblasts and have decreased thrombogenicity in comparison to pristine PLA films. ${ }^{24}$ In another study carbon nanoparticles revealed moderate toxicity towards MSCs in vitro. ${ }^{25}$ Few-layer graphene has been reported to increase extracellular generation of reactive oxygen species ${ }^{26}$ which is proposed to be a leading mechanism for toxicity of engineered nanomaterials. ${ }^{27}$

PTMC is an aliphatic polymer synthesized via the ring opening polymerization of trimethylene carbonate. ${ }^{28}$ It is a highly flexible elastomer making it an attractive material for mimicking soft but strong tissue matrices, such as large veins and arteries. ${ }^{29}$ PTMC is a surface eroding polymer with enzymes playing an important role in its in vivo erosion. ${ }^{30}$ It has been shown that PTMC networks with excellent mechanical properties can be prepared by photo-crosslinking PTMC oligomers end-functionalized with methacrylate groups (PTMC macromers). Increasing the molar mass of the oligomers significantly enhances the mechanical properties of the resulting networks. ${ }^{31}$

In this work, the effect of graphene addition on the properties of UV-crosslinked PTMC networks has been investigated. The processability of the materials was examined through the additive fabrication of multi-layered 3D scaffolds. Compatibility of the composite scaffolds and equivalent 2D films was tested with human MSCs. Moreover, the effect of ES via composite films was evaluated for MSCs under osteogenic differentiation conditions. 


\section{Experimental Section}

Materials: Trimethylene carbonate (1,3-dioxane-2-one, TMC) was obtained from ForYou Medical (China) and used as received. Graphite powder was obtained from Bay Carbon. $N, N$ dimethylformamide (DMF), trimethylamine (TEA), phosphorus pentoxide $\left(\mathrm{P}_{2} \mathrm{O}_{5}\right)$, trimethoxysilylpropylmethacrylate, hydrazine monohydrate $\left(\mathrm{N}_{2} \mathrm{H}_{4} 64-65 \%\right.$, reagent grade, 98\%), ethylene carbonate, trimethylolpropane, stannous octoate $\left(\operatorname{Sn}(\mathrm{Oct})_{2}\right)$, hydroquinone, methacrylic anhydride and triethylamine were sourced from Sigma-Aldrich. Chloroform, potassium persulfate $\left(\mathrm{K}_{2} \mathrm{~S}_{2} \mathrm{O}_{8}\right)$ and potassium permanganate $\left(\mathrm{KMnO}_{4}\right)$ were obtained from Chem-Supply. Sulphuric acid $\left(\mathrm{H}_{2} \mathrm{SO}_{4}\right)$ and $30 \%$ hydrogen peroxide $\left(\mathrm{H}_{2} \mathrm{O}_{2}\right)$ were purchased from Ajax Finechem. 1-[4-(2-hydroxyethoxy) phenyl]-2-hydroxy-2-methyl-1-propane-1-one (Irgacure 2959) was purchased from Ciba (Ciba®, Switzerland). Dichloromethane (>99.5\%) was purchased from VWR chemicals, Belgium. Milli-Q water with a resistivity of $18.2 \mathrm{~m} \Omega$ $\mathrm{cm}^{-1}$ was used in all preparations.

\section{Sample Preparation}

Preparation of DMF-dispersed chemically converted graphene (CCG): The DMF-dispersed graphene dispersions were prepared through chemical reduction of graphene oxide (GO) to graphene nanosheets (CCG) followed by dispersing the nanosheets in DMF. GO was synthesized from natural graphite using a modified Hummers' method in two steps using $\mathrm{K}_{2} \mathrm{~S}_{2} \mathrm{O}_{8}, \mathrm{P}_{2} \mathrm{O}_{5}$ and $\mathrm{H}_{2} \mathrm{SO}_{4}$ followed by $\mathrm{H}_{2} \mathrm{SO}_{4}, \mathrm{KMnO}_{4}$ and $\mathrm{H}_{2} \mathrm{O}_{2}$ to achieve better oxidation. ${ }^{32-}$ ${ }^{33} \mathrm{GO}$ was then chemically converted to graphene (CCG) in aqueous media using hydrazine and ammonia at $90^{\circ} \mathrm{C} .{ }^{34}$ Addition of excess amount of hydrazine followed by acidification resulted in the formation of graphene powder. After filtration, washing and drying, the graphene powder was dispersed in DMF using sonication and addition of TEA to give a 0.5 $\mathrm{mg} \mathrm{ml}^{-1}$ stable homogeneous dispersion of graphene nanosheets with a sheet size of $\sim 400$ nm. ${ }^{35}$ 
Preparation of PTMC macromers: PTMC macromers were prepared according to previously described methods. ${ }^{31}$ In short, a 3-armed PTMC oligomer was synthesized by ring opening polymerization of TMC using trimethylolpropane and $\mathrm{Sn}(\mathrm{Oct}) 2$ as initiator and catalyst respectively. The monomer and initiator were charged in a silanized 3-necked flask and polymerized for 3 days at $130^{\circ} \mathrm{C}$ under argon atmosphere. The molar mass of the oligomer, as determined by ${ }^{1} \mathrm{H}-\mathrm{NMR}$ analysis, was $19.3 \mathrm{~kg} \mathrm{~mol}^{-1}$. The oligomer was dissolved in dry dichloromethane and reacted for 5 days at RT with methacrylic anhydride $(2.5 \mathrm{~mol} / \mathrm{mol}$ oligomer) in the presence of trimethylamine (2.5 mol per mol oligomer) and $0.1 \mathrm{wt} \%$ hydroquinone as inhibitor to prevent premature crosslinking. This resulted in photocrosslinkable macromers functionalized with methacrylate end-groups. Purification was done by precipitation in cold methanol and subsequent drying under vacuum. Analysis by ${ }^{1} \mathrm{H}-\mathrm{NMR}$ showed that the degree of functionalization was $77 \%$.

Preparation of PTMC composites: To prepare PTMC dispersions for film preparation, PTMC macromer and photoinitiator (Irgacure 2959, $5 \mathrm{wt} \%$ relative to the macromer) were dissolved in DMF or DMF-dispersed graphene (CCG). After stirring for 2 hours, the dispersion was cast onto a petri dish and the solvent was evaporated. The resultant film was then crosslinked by UV-irradiation (using a Hanovia 125 Watt UV-lamp) for $10 \mathrm{~min}$, followed by soaking in chloroform and washing with acetone/water mixtures (80/20), decreasing the acetone/water ratio stepwise until the films were in pure water. The samples were labelled according to the weight percentage of their graphene content, e.g. PTMC-CCG $3 \%$ contained 3 wt. $\%$ graphene. Films were used for material characterization and were cut into circular shapes (diameter $1 \mathrm{~cm}$ ) for cell culture.

PTMC-CCG 3\% dispersion used for electrical stimulation substrates were spray-coated using a SONO-TEK spray coating system (Sono-Tek Corporation, USA) on trimethoxysilylpropylmethacrylate-treated and ozone-treated glass slides. The coated glass 
slides were fixed on a $80^{\circ} \mathrm{C}$ heated platform to evaporate the solvent. The samples were then UV-irradiated and washed as above. 4-well chambers (Nunc) were attached to spray-coated glass slides. Electrical connections were attached to both ends of the conductive film outside the chambers.

$3 D$ printing of PTMC scaffolds: PTMC scaffolds were printed by modifying the method used by Bat et al. ${ }^{29}$ using a KIMM SPS1000 bioplotter extrusion printing system. PTMC macromer was dissolved in DMF or DMF-dispersed graphene (based on the desired percentage of CCG in the product) followed by addition of ethylene carbonate ( $80 \mathrm{wt} . \%$ relative to the macromer) and photoinitiator (as above). After evaporation of DMF on a hotplate and vacuum oven, the resulting material was printed at $60-150^{\circ} \mathrm{C}$ and $100-200 \mathrm{kPa}$ nitrogen pressure, depending on the graphene content of the sample, as graphene addition increases the viscosity of the material (Figure S 2). The ethylene carbonate was crystallized by exposing the structure to liquid nitrogen vapor during the printing and the printed scaffolds were kept at $4^{\circ} \mathrm{C}$. The samples were then crosslinked by exposing them to UV irradiation for 10-15 min. The scaffolds were kept in deionized water at $4^{\circ} \mathrm{C}$ for 4 days followed by chloroform, ethanol and acetone/water washing to remove ethylene carbonate and the other possible residues.

Material characterisation: The number average molar mass (Mn) of the oligomers and the monomer conversion were determined by ${ }^{1} \mathrm{H}-\mathrm{NMR}$ (Varian Inova $400 \mathrm{MHz}$, Brüker, Germany).Thermogravimetric analysis (TGA) was performed using a TA Instruments TGA Q500 on $10 \mathrm{mg}$ of samples with a heating rate of $10^{\circ} \mathrm{C} \mathrm{min}^{-1}$ under a nitrogen atmosphere. Differential Scanning Calorimetry (DSC) analysis was performed on a DSC Q100 from TA Instruments at a rate of $10^{\circ} \mathrm{C} \mathrm{min}^{-1}$ between -50 to $180^{\circ} \mathrm{C}$. Scanning electron microscopy (SEM) images were taken with a field-emission SEM (JEOL JSM-7500FA). To prepare samples for cross-sectional images, the films were frozen in liquid nitrogen, fractured and sputter-coated (EDWARDS Auto 306) with a thin layer of platinum ( 12 nm thickness). 
Raman spectra were recorded on a Jobin Yvon Horiba HR800 Raman system using a 632 nm laser line and a 300-line grating. Fourier transform infrared (FTIR) spectra were measured between 400 and $4000 \mathrm{~cm}^{-1}$ on a Shimadzu IRPrestige-21 infrared spectrometer. The spectra were obtained using attenuated total reflection (ATR) on $1 \times 1 \mathrm{~cm}$ films $\mathrm{t}$.

The mechanical properties of all samples were tested using an Instron 5566 Universal Testing Machine (USA) with Trapezium X software. To prepare samples for mechanical property tests, the samples were cut into strips with width of $3 \mathrm{~mm}$ and length of $20 \mathrm{~mm}$. The tensile properties of the samples were measured at a constant rate of $10 \mathrm{~mm} \mathrm{~min}^{-1}$. Rheological properties were studied using a rheometer (AR-G2, TA Instruments) with a stainless steel plate diameter of $25 \mathrm{~mm}$. The surface conductivity of the composite films was measured using two-point probe and four point probe methods with Fluke 287 True-RMS and Jandel RM3 Conductivity Meters. All sonication was done using a Branson Digital Sonicator (S450D, 500W, 40\% amplitude).

\section{Culture and characterization of cells}

Isolation and culture of mesenchymal stem cells: Adipose tissue harvests were obtained from surgical procedures on 3 female donors with an average age of $47 \pm 19$ years in the Department of Plastic Surgery, Tampere University Hospital. The tissue harvesting and the use of MSCs were conducted in accordance with the Ethics Committee of the Pirkanmaa Hospital District (R03058). MSCs were retrieved from adipose tissue using a previously described isolation method. ${ }^{36-37}$ In brief, the adipose tissue samples were digested with collagenase type I (1.5 mg ml${ }^{-1}$; Invitrogen, USA). The isolated MSCs were maintained and expanded in T-75 $\mathrm{cm}^{2}$ polystyrene flasks (Nunc, Roskilde, Denmark), and cryopreserved in freezing solution containing 10\% dimethyl sulphoxide (Hybri-Max DMSO; Sigma-Aldrich, USA). Cells were thawed in maintenance medium consisting of Dulbecco's Modified Eagle Medium /Ham's Nutrient Mixture F-12 (DMEM/F-12 1:1, Invitrogen, USA), 10\% foetal 
bovine serum (FBS, Invitrogen), 1\% L-glutamine (GlutaMAX I; Invitrogen) and 1\% penstrep (100 $\mathrm{U} \mathrm{ml}^{-1}$ penicillin, $0.1 \mathrm{mg} \mathrm{ml}^{-1}$ streptomycin; Lonza).

MSCs of passage 1 were harvested and analyzed by flow cytometry (FACS Aria; BD Biosciences) as previously described ${ }^{38}$ Monoclonal antibodies against CD14-PE-Cy7, CD19PE-Cy7, CD45RO-APC, CD73-PE, CD90-APC (BD Biosciences, USA); CD34-APC, HLADR-PE (Immunotools); CD105-PE (R\&D Systems, USA) were used. Analysis was performed on 10,000 cells per sample, and unstained cell samples were used to compensate for the background autofluorescence levels.

Positive expression ( $\geq 75 \%)$ of CD73, CD90, and CD105, lack of expression $(\leq 2 \%)$ of CD14, CD19, CD45, and HLA-DR, and moderate expression (2-50\%) of CD34 (Table S-1) was detected. Apart from the highly varying expression profile of CD34, this expression profile is in accordance with that defined by the Mesenchymal and Tissue Stem Cell Committee of the ISCT. ${ }^{39}$ Varying expression of CD34 has been shown to be typical for MSCs from adipose tissue. $^{40-45}$

Prior to cell seeding, films, ES chambers with spray-coated PTMC-CCG 3\%, and scaffolds were disinfected in $70 \%$ ethanol for $15 \mathrm{~min}$, rinsed 3 times with phosphate-buffered saline (PBS) and incubated with DMEM supplemented with $1 \%$ pen-strep overnight. For the material comparison experiments with films, cylinder-shaped inserts were used to hold the films in place in 48-well cell culture well plates (Greiner Bio One). Cells were seeded at a density of 5200 cells $\mathrm{cm}^{-2}$ and the experiment was repeated twice with 2 different donor lines.

In the case of the ES experiments with spray-coated PTMC-CCG 3\%, cells were seeded at a density of 18,400 cells $\mathrm{cm}^{-2}$ in the first experiment, 11,300 cells $\mathrm{cm}^{-2}$ in the second experiment, and 4,400 cells $\mathrm{cm}^{-2}$ in the third experiment. Each experiment was performed with a different donor line. Higher cell density in the first ES experiment (donor 1) was used 
because of earlier onset of osteogenic induction to ensure that the cells would remain densely packed and in the elongated morphology that had developed during the osteogenic induction. In addition, as the experiment continued for 5 additional days, cells were allowed to reach confluency earlier. For the second ES experiment (donor 2), lower cell seeding density was used to allow longer culture times in the ES chambers. However, cells in the unstimulated control group had detached on the $12^{\text {th }}$ day due to high confluency and hence cell density and the cell culture time was decreased in the third ES experiment (donor 3) to avoid the risk of cell detachment. Scaffolds were held in place with the cylinder-shaped inserts and seeded with 9,000 cells in $0.7 \mathrm{ml}$.

Electrical stimulation of mesenchymal stem cells: Pulsed biphasic current with a frequency of $100 \mathrm{~Hz}$, pulse width of $2.5 \mathrm{~ms}$, and current of $10 \mu \mathrm{A}$ was applied across the spray-coated glass slides for $4 \mathrm{~h}$ per day for up to 7 days. Current was generated by a DS8000 Digital Stimulator and A365 Isolator units (World Precision Instruments, USA) and monitored with an e-corder system (eDAQ). Cells were cultured in osteogenic induction medium consisting of maintenance medium supplemented with $5 \mathrm{nM}$ dexamethasone, $250 \mu \mathrm{M}$ 1-ascorbic acid-2phosphate, and $10 \mathrm{mM} \beta$-glycerophosphate (Sigma-Aldrich). In the first experiment cells were primed in osteogenic induction medium 4 days before cell seeding on the films and ES was initiated the day after cell seeding. For the 2 latter experiments, osteogenic induction medium was added the day after cell seeding and ES was initiated 3 days after cell seeding.

Cell attachment and viability: Cell attachment and viability were evaluated qualitatively in ES experiments using calcein AM (Molecular Probes, Life Technologies) to visualize viable cells and propidium iodide (Sigma-Aldrich) to visualize dead cells according to manufacturers' protocols. Samples were examined with a fluorescence microscope (Zeiss Axioimager). Images were compiled using Paint.Net version 4.0.9. Contrast and brightness was altered to better expose all the cells in all samples. 
Due to the high autofluorescence of the 3D-printed scaffolds viability of MSCs with calcein and PI could not be evaluated on these samples. Cells on the scaffolds were rinsed with PBS and fixed with $3.7 \%$ paraformaldehyde for 10 min following permeabilization of cells by 0.1\% Triton X-100 (Sigma-Aldrich) for $10 \mathrm{~min}$. Subsequently, samples were incubated in solutions of $165 \mathrm{nM}$ Alexa 488-Phalloidin (Molecular Probes, Life Technologies) in $100 \mu \mathrm{L}$ of $1 \%$ bovine serum albumin (Sigma) to allow imaging of the F-actin in cytoskeletons of MSCs.

Cell proliferation: Cell proliferation was studied using CyQuant ${ }^{\circledR}$ Cell Proliferation Assay Kit (Molecular Probes ${ }^{\circledR}$ ) according to the manufacturer's protocol. In brief, on the days of the analyses, samples were washed with PBS and lysed with trituration in $0.1 \%$ Triton-X 100 (Sigma-Aldrich) in PBS (lysis buffer) and stored at $-80{ }^{\circ} \mathrm{C}$ until analysis. After thawing, 20 $\mu \mathrm{L}$ of each sample lysate was pipetted into triplicate wells of a 96-well plate. Lysates were mixed with $180 \mu \mathrm{L}$ CyQuant ${ }^{\circledR}$ GR dye in lysis buffer. The fluorescence was measured using a microplate reader (FLUOstar Omega spectrometer, Brightside Scientific, Sydney) at $480 \mathrm{~nm}$ (Ex) $/ 520 \mathrm{~nm}(\mathrm{Em})$.

Alkaline phosphatase activity: Alkaline phosphatase (ALP) activity was determined from the same Triton-X 100 lysates as the cell proliferation assays. The samples were incubated with a 1:1 mixture of alkaline buffer solution (1.5 M 2-amino-2-methyl-1-propanol, pH 10.3; SigmaAldrich) and stock substrate solution (p-nitrophenyl phosphate, $4 \mathrm{mg} \mathrm{ml}^{-1}$; Sigma-Aldrich) at $37^{\circ} \mathrm{C}$ for $15 \mathrm{~min}$. The reaction was stopped with $1.0 \mathrm{M}$ sodium hydroxide. The intensity of the color was measured at $405 \mathrm{~nm}$ using a microplate reader. ALP activity was normalized to DNA content.

Quantitative real-time PCR: RNA was isolated with an RNA isolation Mini Kit (Bioline, Sydney) according to the manufacturer's protocol. An additional RNA purification step was performed by using DNase clean-up kit (Promega) according to manufacturer's protocol. 
RNA concentration was measured with Nanodrop 2000 (ThermoScientific).The absence of DNA contamination in the purified samples was confirmed by conversion to cDNA in the absence of the transcription enzyme using the Tetro cDNA Synthesis kit (Bioline) and PCR performed with C100 TouchThermal Cycler (Bio-Rad, Hercules, USA). The gene expression of the osteogenic-associated genes ALP, Runx2, Collagen type I (Col I) were measured with 2 technical replicates. The primer sequences with accession numbers are presented in Table $\mathbf{S}$ 2. The relative gene expression was normalized to human acidic ribosomal phosphoprotein P0 (hRPLP0) and efficiencies (accepted range 90-110\%) were taken into account by using following equation

ratio $=\frac{E(\text { target })^{\Delta C t \text { target }(\text { control-treated })}}{E(\text { ref })^{\Delta C t \text { ref(control-treated })}} 46$

Each reaction mixture contained $14 \mathrm{ng}$ of cDNA, $300 \mathrm{nM}$ forward and reverse primers and SsoFast $^{\mathrm{TM}}$ EvaGreen ${ }^{\circledR}$ Supermix (Bio-Rad). The qRT-PCR reactions were performed in a C1000 Touch Thermal Cycler CFX96 Real-time System (Bio-Rad) using $95{ }^{0} \mathrm{C}$ for $30 \mathrm{~s}$ enzyme activation, 40 cycles at $95{ }^{\circ} \mathrm{C}$ for $5 \mathrm{~s}$ denaturation followed by annealing and extension for $5 \mathrm{~s}$ at $60{ }^{\circ} \mathrm{C}$.

Statistical analysis: The statistical analyses of DNA content, ALP activity and gene expression were performed with IBM SPSS statistics version 21. The relative DNA content comparison between PTMC-CCG, PTMC and control polystyrene cell culture plates was analyzed by One Way ANOVA with Bonferroni correction. The difference between stimulated and unstimulated samples was evaluated with Student's t-test and the equal variance assumption was checked by Levene's Test. The data were combined and presented as mean \pm standard deviation (SD) and the results were considered statistically significant when $p<0.05$. 


\section{RESULTS AND DISCUSSION}

This is the first study to the best of our knowledge to add graphene as filler in a PTMC matrix for developing a conductive, flexible, and biodegradable composite material. We also successfully created scaffold structures of the composites by 3D printing, which opens further possibilities for rapid manufacturing of tailor-made scaffold structures. The electrical performance of the composite was tested for enhancing osteogenic differentiation of MSCs under ES. Conductive materials have rapidly gained interest in bone tissue engineering due to the high potential of ES as a trigger towards osteogenic differentiation of stem cells. ${ }^{37,40,47-48}$ However, only polypyrrole-based conductive scaffold materials have so far been tested for administering ES to MSCs in order to promote osteogenic differentiation. ${ }^{37,40,48}$ Another (even greater) area for conductive and flexible materials lies in neural applications for fabricating neural conduits and electrode materials. ${ }^{49}$ Homogeneous dispersions of graphene nanosheets in DMF ${ }^{35}$ were utilized for developing the biocomposites. As shown in previous work $^{13-14,16,50}$, this stable DMF-dispersed graphene provides uniform dispersions of graphene nanosheets in the polymer matrix to develop processable composites with excellent compatibility with the tested cell type through a facile mixing/casting method.

3.1. Thermogravimetric Analysis. The thermal behavior of the PTMC macromer as well as PTMC films with $0,0.5$ and 3 wt.\% graphene content after UV-crosslinking is shown in Figure 1. The PTMC macromer shows two weight loss regions. A slow weight loss between 110 to $250^{\circ} \mathrm{C}$, which could be attributed to the loss of methyl methacrylate and the solvent residues, followed by a major loss at $\sim 250^{\circ} \mathrm{C}$ due to the decomposition of the PTMC oligomers. After UV-crosslinking, the decomposition temperature of the polymer was increased to around $280^{\circ} \mathrm{C}$ due to formation of PTMC networks. Addition of graphene improved the thermal stability of the polymer i.e. PTMC with 3 wt.\% CCG showed an increased decomposition temperature up to $290^{\circ} \mathrm{C}$. The decomposition of the composites 
takes place through a single stage starting at $\sim 260^{\circ} \mathrm{C}$ and no melting peak was observed in the sample with 3wt.\% CCG (Figure S 1), indicating successful UV-crosslinking of the graphene/PTMC samples and formation of amorphous network structures.

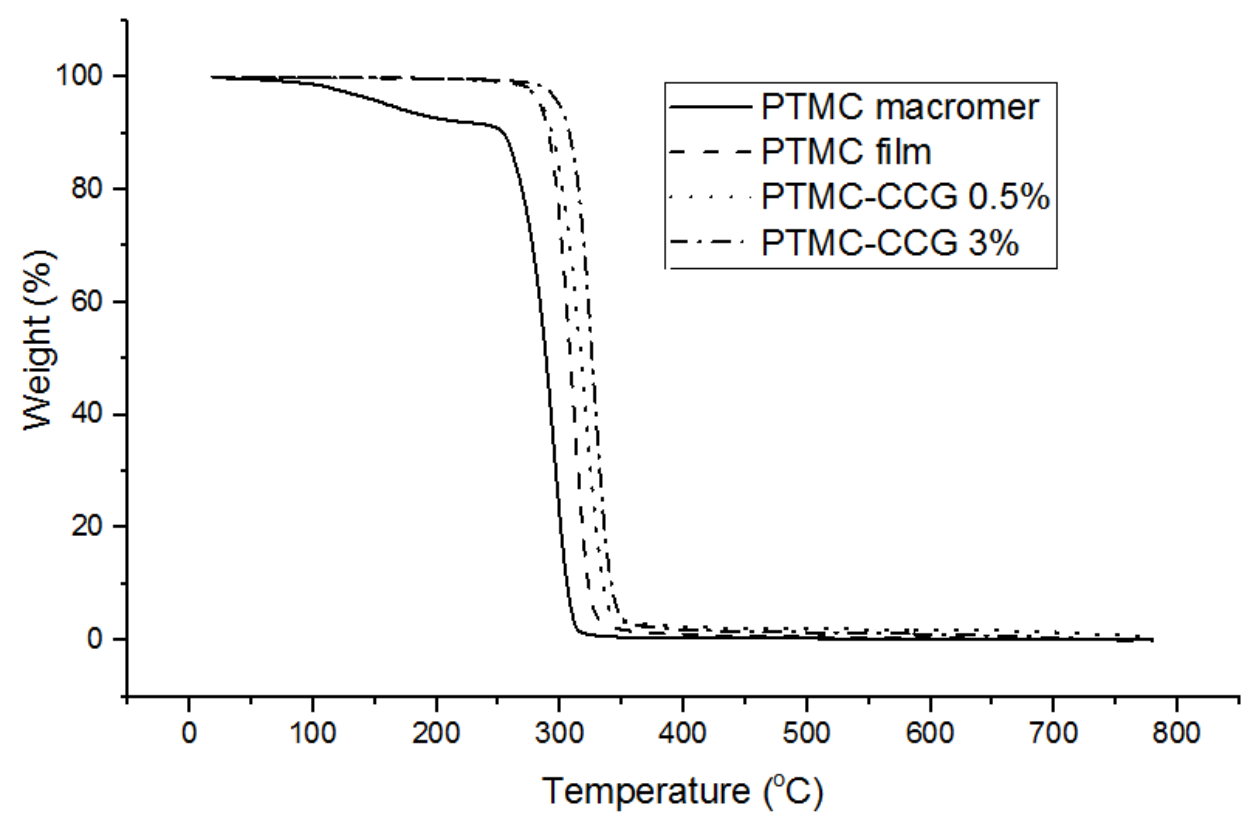

Figure 1. Thermogravimetric analysis of PTMC macromer, PTMC film and PTMC composites with 0.5 and 3 wt.\% graphene content.

3.2. Scanning Electron Microscopy. SEM images of PTMC samples with and without graphene are shown in Figure 2. A significant difference was observed between the crosssectional morphologies of the PTMC macromer and the film after crosslinking, which demonstrates a stratified, uniform structure across the sample (Figure 2B). PTMC-CCG 3\% composite showed a condensed inner structure with uniform orientation, which may indicate homogenous dispersion and orientation of graphene sheets in the polymer matrix (Figure 2D). Both PTMC and the PTMC-CCG composite show uniform surface morphology with no observable cracks or agglomeration, although the graphene addition resulted in increased surface roughness in the composite (Figure 2E). The morphological changes in the surface and cross-sections of the samples toward more condensed and oriented structures accounts for the improvement in mechanical properties of the composites. 

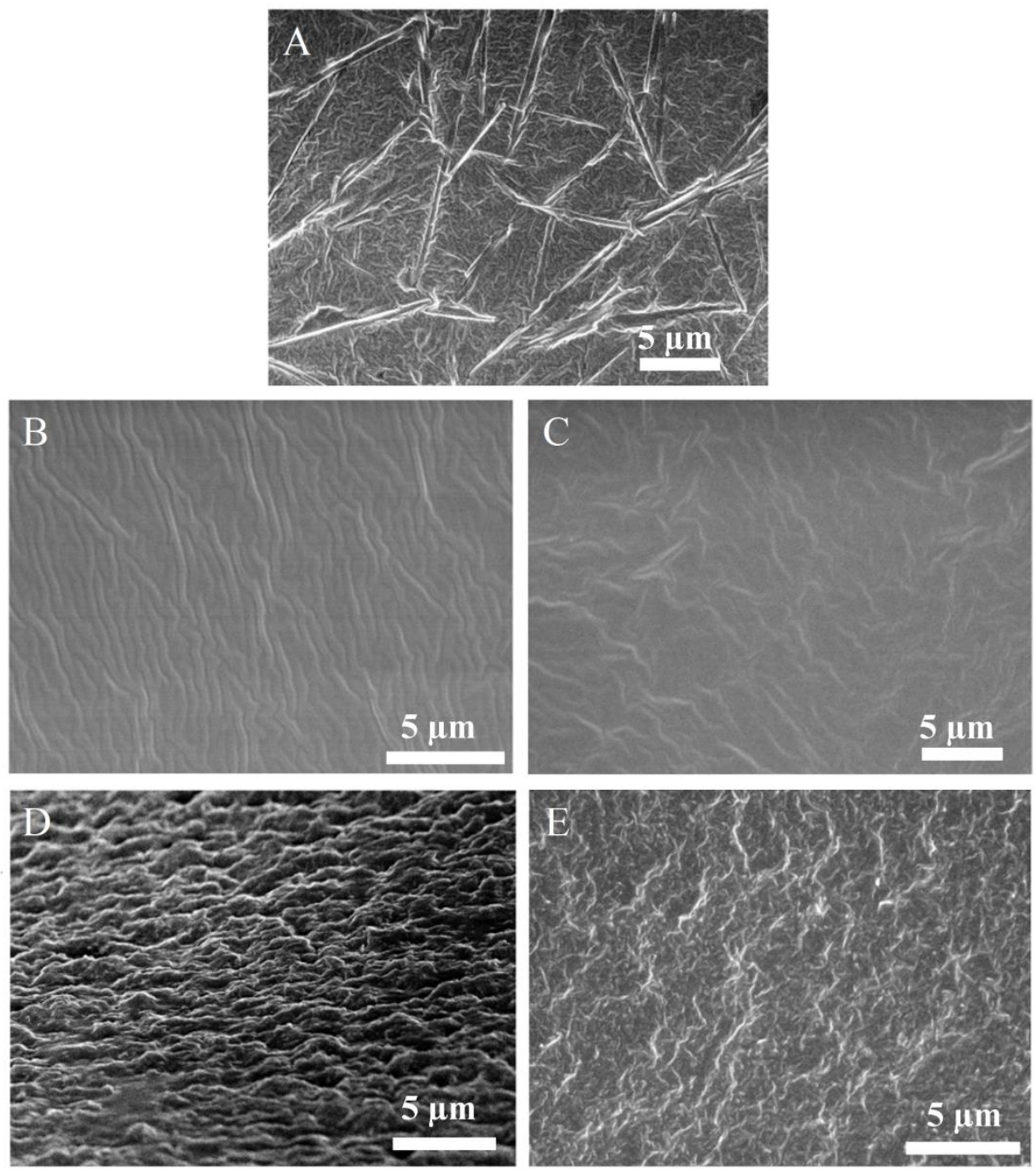

Figure 2. SEM images of cross-sections (A,B,D) and surfaces (C,E) of PTMC macromer (A), PTMC film (B,C) and PTMC-CCG 3\% composite (D,E).

3.3. Material Composition. Raman spectra were collected on the samples between 200 and $4000 \mathrm{~cm}^{-1}$ (Figure 3A). In the PTMC macromer, the $=\mathrm{CH}_{2}$ bending vibrations of the methacrylic group appear at $945 \mathrm{~cm}^{-1}$. The peaks at $1740 \mathrm{~cm}^{-1}$ and $1296 \mathrm{~cm}^{-1}$ are assigned to $\mathrm{C}=\mathrm{O}$ stretching in ester bonds and the $\mathrm{C}-\mathrm{O}-\mathrm{C}$ stretch, respectively. The bands around 1480 $\mathrm{cm}^{-1}$ correspond to $\mathrm{CH}_{3}$ and the signals at 2900 to $3000 \mathrm{~cm}^{-1}$ are associated with the $\mathrm{CH}$ stretching. After crosslinking, a significant decrease in the intensity of $=\mathrm{CH}_{2}$ peak followed by an increase in the $\mathrm{CH}$ stretching region was observed, confirming the formation of crosslinks in the PTMC. In the spectra of the graphene composites, two sharp peaks at 1329 
and $1586 \mathrm{~cm}^{-1}$ are associated with the D and $\mathrm{G}$ bands of the incorporated graphene sheets. By increasing the graphene content, only graphene peaks are visible in the spectra due to their higher intensity than the polymer peaks. The position and the ratio of $D$ and $G$ bands of the incorporated graphene have barely changed compared to the pristine graphene, indicating that there is negligible change in the $\mathrm{sp}^{2}$ domains and the structure of the graphene. ${ }^{51-52}$

FTIR spectra of PTMC and PTMC composites are demonstrated in Figure 3B. In the spectrum of the macromer, the absorbance peak at $1740 \mathrm{~cm}^{-1}$ is assigned to $\mathrm{C}=\mathrm{O}$ stretching in the ester bond and the $1234 \mathrm{~cm}^{-1}$ band associates with C-O-C groups. The peaks at $1411 \mathrm{~cm}^{-1}$ and $1477 \mathrm{~cm}^{-1}$ correspond to $\mathrm{CH}_{3}$ bands. The peaks at 922 and $945 \mathrm{~cm}^{-1}$ are attributed to the bending vibrations of the $=\mathrm{CH}_{2}$ in the methacrylic group and the weak peak at $1307 \mathrm{~cm}^{-1}$ could be attributed to $\mathrm{C}=\mathrm{C}$ bonds. After crosslinking, the $=\mathrm{CH}_{2}$ peaks were replaced by two new peaks with decreased intensities and the peak at $1307 \mathrm{~cm}^{-1}$ disappeared, indicating the elimination of most of the double bonds due to formation of crosslinks in the polymer. The spectra of the PTMC-CCG composite is similar to the PTMC polymer, confirming that the addition of graphene has not affected the major structure of PTMC even after increasing the graphene content to $3 \mathrm{wt} . \%$. 
A

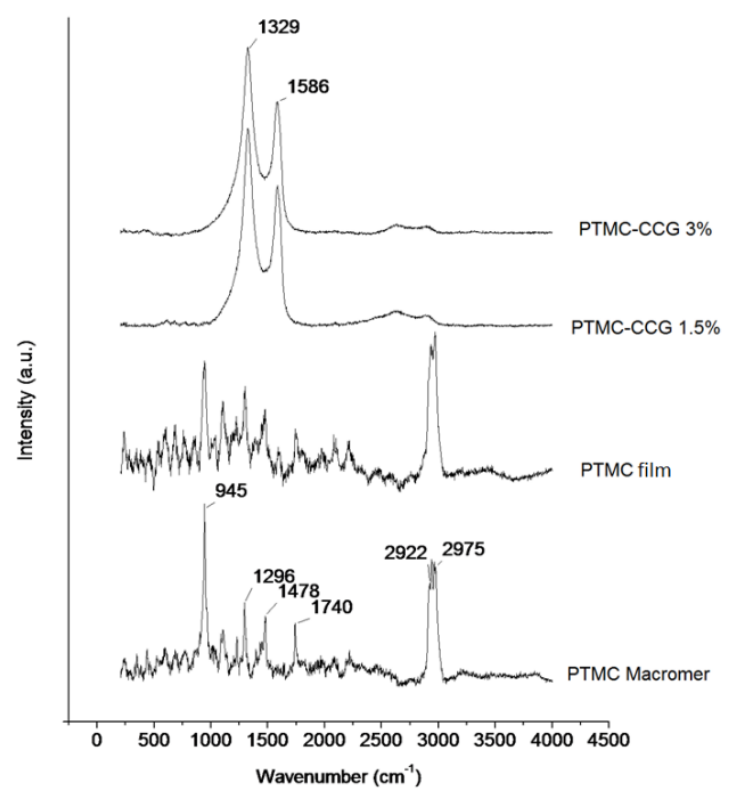

B

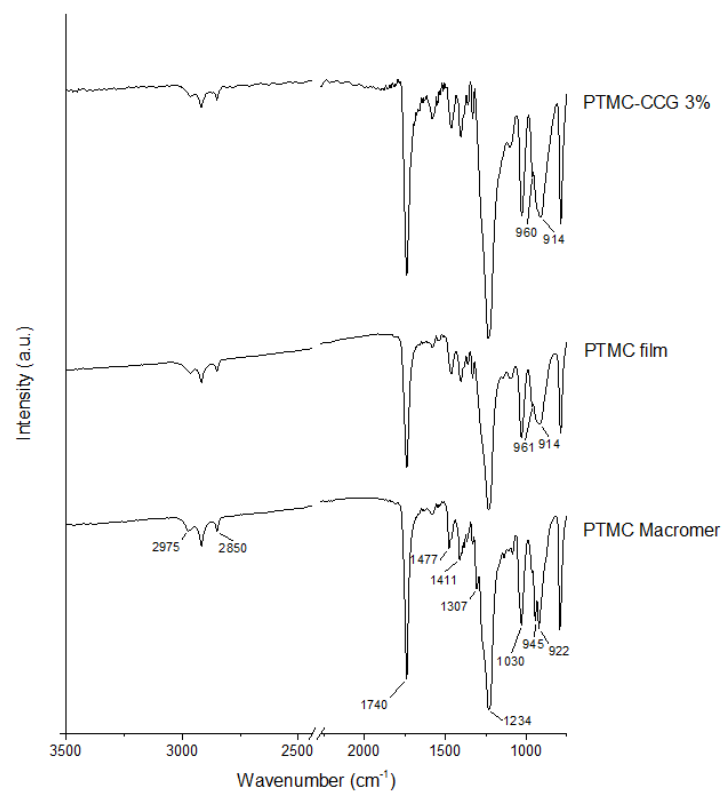

Figure 3. Raman (A) and FTIR (B) spectra of PTMC macromer, PTMC film and PTMC composites.

3.4. Electrical and Mechanical Properties. The electrical conductivity of the samples increased with addition of graphene from $\sim 1 \times 10^{-3} \mathrm{~S} \mathrm{~m}^{-1}$ in samples with $0.5 \mathrm{wt} . \%$ CCG to $1 \times 10^{-1} \mathrm{~S} \mathrm{~m}^{-1}$ in composites with $3 \mathrm{wt} . \% \mathrm{CCG}$ (Figure 4A). The conductivities of the films under cell culture conditions were expected to be in similar ranges because PTMC-CCG has very low water uptake. Given the insulating nature of the pristine biomaterials, with electrical conductivities ranging from $10^{-13}$ to $10^{-8} \mathrm{~S} \mathrm{~m}^{-1}$, it can be concluded that very low graphene loadings $(\sim 0.5$ wt. $\%)$ can induce at least 5 orders of magnitude increase in the electrical conductivity of PTMC. The conductivity of $3 \mathrm{wt} . \%$ PTMC-CCG is in the range of that of muscle tissue (0.4-0.47 $\left.\mathrm{S} \mathrm{m}^{-1}\right)$ and higher to that of bone tissue $\left(0.02-0.07 \mathrm{~S} \mathrm{~m}^{-1}\right) .53$

In electrical stimulation experiments, generated potentials over the electrical circuits were monitored daily up to the maximum of 10 days of ES (Figure $\mathbf{S ~ 3 ) . ~ T h e ~ p o l a r i z a t i o n ~}$ 
resistance did not change through the duration of ES experiments, implying high electrochemical stability of the coatings.

Figure 4B presents the typical stress-strain curves of PTMC and graphene PTMC composites. The detailed data are represented in Table 1. Increasing the graphene content improved the mechanical properties of PTMC. Slight improvements in tensile strength of PTMC on addition of 0.5 wt. $\%$ graphene was increased to $83 \%$ and $112 \%$ on addition of 1.5 and 3 wt.\% CCG, respectively. The Young's modulus gradually increased with increasing CCG content as well, the composite with $3 \mathrm{wt} \%$ CCG showing a Young's modulus of $19 \mathrm{MPa}$, which is around $500 \%$ higher than that of PTMC. Addition of graphene did not affect the elongation at break of the samples, but provided some improvement in the strain of the samples with 3 wt.\% CCG content. The results indicate homogenous dispersion of graphene nanosheets in the PTMC polymer matrix without causing structural defects, which resulted in significant mechanical enhancement in the composites.
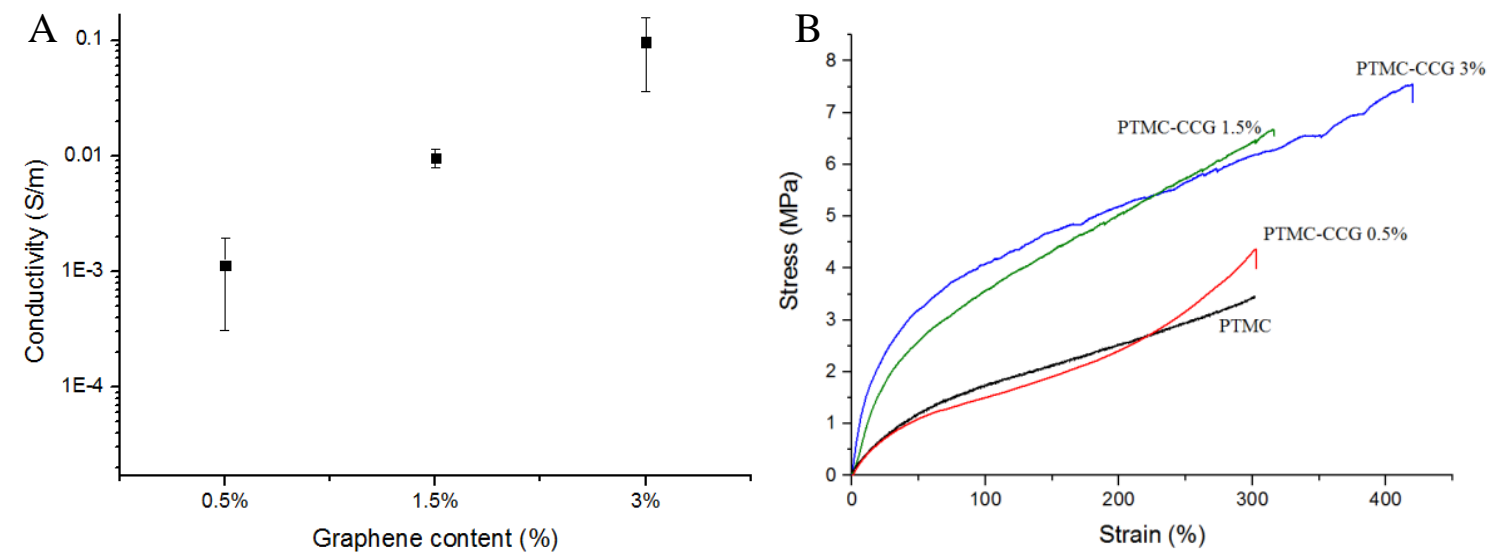

Figure 4. Electrical conductivity (A) and stress-strain curves (B) of PTMC films with different graphene contents. 
Table 1. Mechanical properties of PTMC films with different graphene contents.

\begin{tabular}{cccc}
\hline Sample & Tensile strength [MPa] & Elongation at break [\%] & $\begin{array}{c}\text { Young's Modulus } \\
\text { [MPa] }\end{array}$ \\
\hline PTMC & $3.5 \pm 0.4$ & $302 \pm 7$ & $3.2 \pm 0.2$ \\
PTMC-CCG 0.5\% & $3.8 \pm 0.4$ & $303 \pm 9$ & $3.7 \pm 0.2$ \\
PTMC-CCG 1.5\% & $6.4 \pm 0.3$ & $316 \pm 15$ & $9.4 \pm 0.3$ \\
PTMC-CCG 3\% & $7.4 \pm 0.3$ & $420 \pm 11$ & $19.1 \pm 0.5$ \\
\hline
\end{tabular}

3.5. 3D Printing. Single to multi-layered (up to 7 layers) PTMC and PTMC-CCG scaffolds of $1 \times 1 \mathrm{~cm}$ in dimensions and a pore size of 500-1000 $\mu \mathrm{m}$ (Figure 5) were printed using a KIIM Bioplotter.

Graphene played a role in retaining the structure of the scaffolds. Ethylene carbonate is a solvent that helps scaffolds to retain their structures during printing. After crosslinking, the ethylene carbonate leaches out, resulting in slight deformation of the scaffold structures followed by adhesion of different layers to each other. Graphene helped to retain the structure of the scaffolds after removal of the ethylene carbonate. The graphene scaffolds, even at low graphene content, exhibited a stable structure, with patterns and layers that were better resolved than for the PTMC scaffolds. 

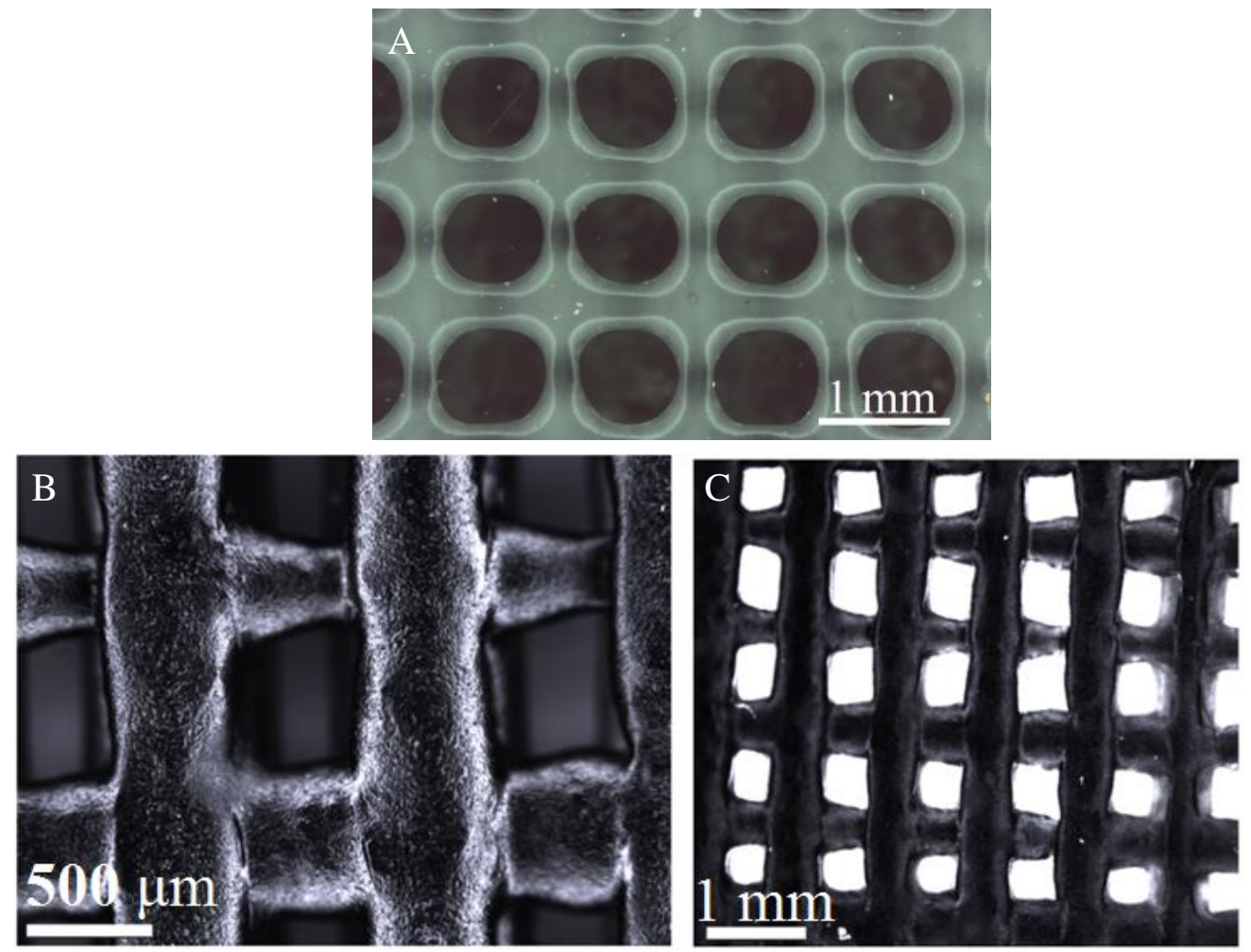

Figure 5. 3D printed PTMC (A) and PTMC-CCG $0.5 \%$ scaffolds at high (B) and low (C) resolution.

3.6. Cell viability, attachment, and proliferation on the composites. MSCs were seeded on glass slides that had been spray-coated with PTMC-CCG 3\%. Cells were similarly viable with and without ES after 7 days in osteogenic medium as shown in Figure 6A-C. Cell densities, morphologies and viability did not differ from polystyrene cell culture plates, indicating that PTMC-CCG 3\% was a suitable substrate for MSCs. 
Phalloidin staining of MSCs on 3D printed PTMC-CCG 0.5\% scaffolds and PTMC scaffolds revealed attached and evenly spread cells throughout both scaffold types as indicated by the flat, adherent morphology of the cells (Figure 6D-E). Addition of graphene did not alter cell number as no significant differences between DNA content of MSC cells on PTMC-CCG $3 \%$ and PTMC were found after 1 and 7 days of culture (Figure S 4).
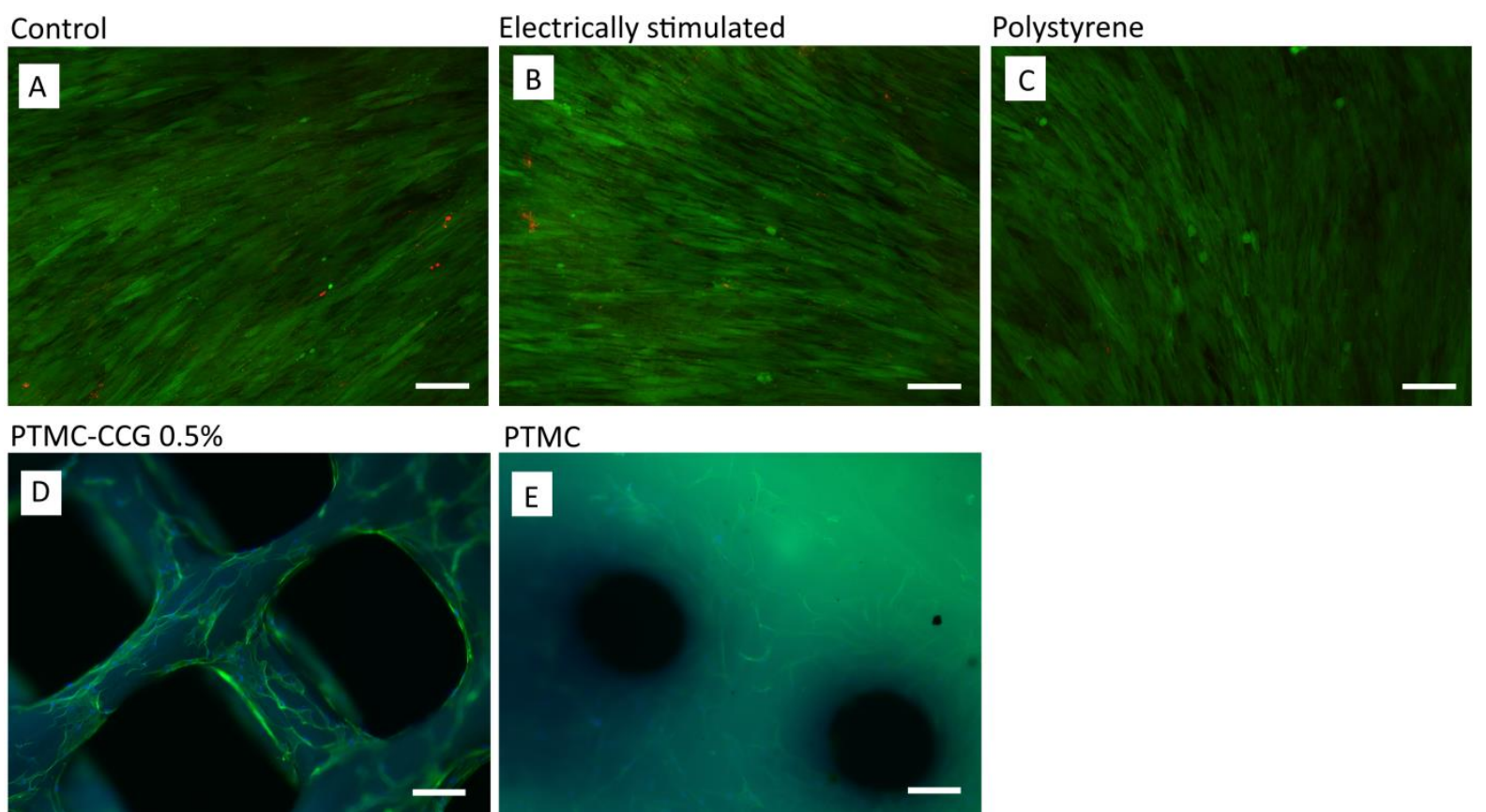

PTMC

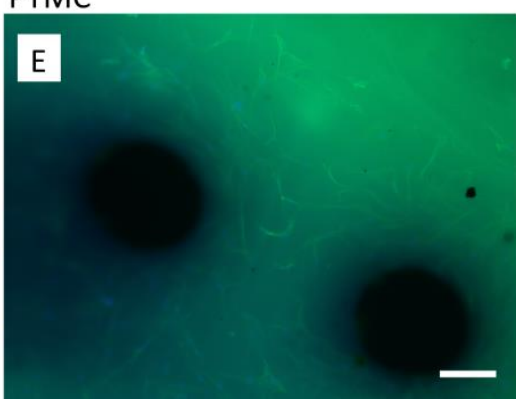

Figure 6. Live/dead stained MSCs were similarly viable on spray-coated PTMC-CCG 3\% without (A) and with (B) ES as well as on PS cell culture plate (C) after 7 days of culture. Scale bars represent $200 \mu \mathrm{m}$. Actin cytoskeleton (phalloidin) staining of MSCs on 3D printed PTMC-CCG $0.5 \%$ and PTMC scaffolds (D,E) after 3 days of culture in maintenance medium. Scale bar $200 \mu \mathrm{m}$.

3.7. Effect of Electrical Stimulation on Mesenchymal Stem Cells. ES was applied through the PTMC-CCG 3\% coated glass slides that were seeded with MSC-cells. ES did not have a statistically significant effect on cell number. After 5 days Donor 2 showed slightly lower cell number under ES (Figure 7A and B) while Donor 3 cells did not differ from the control (Figure 7A). Cell number increased with time with and without ES but was slightly more pronounced for Donor 2 without ES (Figure 7B). 

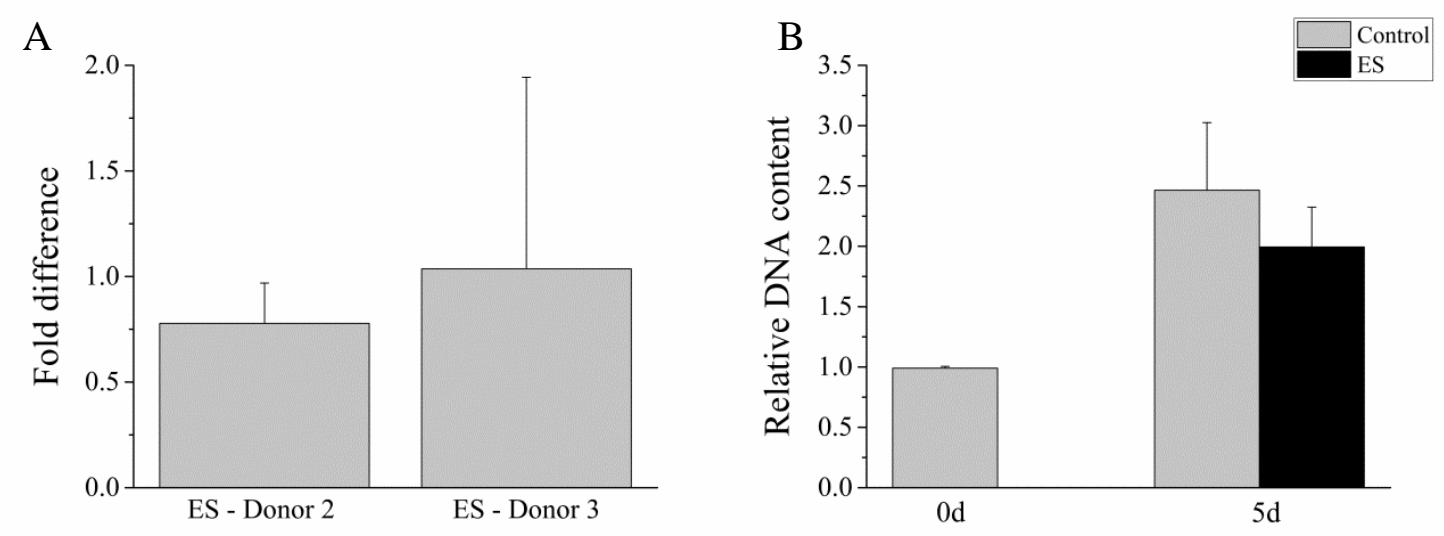

Figure 7. A) Effect of ES on MSCs numbers relative to unstimulated controls. Results are shown as fold difference relative to unstimulated control after 5 days of ES. B) Cell number measured at 2 time points (Donor 2).

When MSCs were primed in osteogenic medium for 5 days before initiation of ES, analyses of gene expression showed upregulation of ALP and Col I after 5 days of ES. The effect of ES on gene expression with and without priming is depicted in Figure 8A. VEGF was unaffected by ES and Runx2 was slightly downregulated with 5 day priming before ES. When osteogenic induction was initiated only 2 days before ES (non-primed), gene expression of MSCs did not show significant differences between the groups after 5 days of stimulation. Therefore priming cells in osteogenic medium for an extended period (5 days) prior to electrical stimulation appeared to enhance the effect of electrical stimulation on changes in gene expression; however, this effect may be contributed to by variations in expression between patients. Hammerick et al. ${ }^{54}$ reported upregulation in ALP and Col I gene expression under pulsed alternating current $\left(6 \mathrm{~V} \mathrm{~cm}^{-1}, 50 \mathrm{~Hz}, 6 \mathrm{~h} /\right.$ day $)$ with mouse MSCs after 21 days of ES. Our results with primed MSCs are in accord with this study. Col $\mathrm{I}$ is the main extracellular matrix protein of bone and therefore Col I gene expression is essential for osteogenic differentiation. In another study ES (sinusoidal, $10 \mathrm{~Hz}, 10$ or $40 \mu \mathrm{A}$, for $6 \mathrm{~h}$ per day) was reported to upregulate Runx2 in human MSCs after 14 days of ES. ${ }^{55}$ The difference between these results and our study, may be due to the shorter time of ES in our study, or the 
different frequencies applied to MSCs. We chose the electrical conditions based on our earlier studies. $^{37,40}$
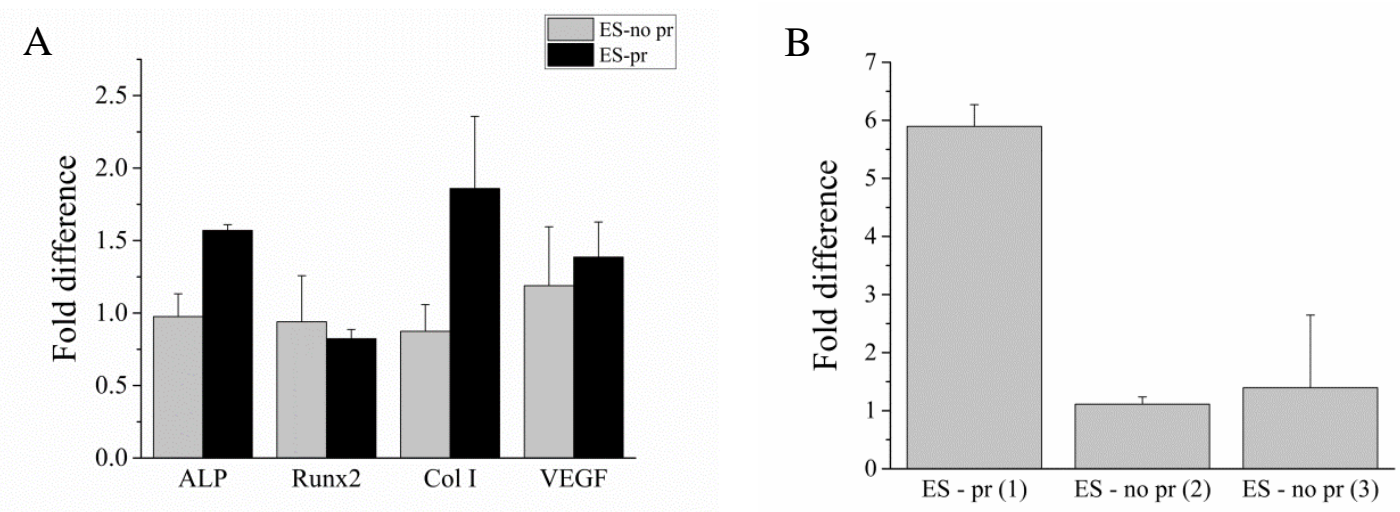

Figure 8. A) Effect of ES on gene expression of MSCs without priming in osteogenic medium (no pr; Donor 1) and with priming (pr; Donor 2). Results are shown as fold difference relative to unstimulated control after 5 days of ES. B) Effect of ES on ALP activity of all donors after 5 days of ES. Donor number is marked in brackets.

As gene expression of ALP under ES differed between primed and non-primed cells, we further tested ALP activity. We found substantially higher ALP activity in primed cells under ES compared to those not under ES for one donor (Donor 1, Figure 8B). However, for Donors 2 and 3, in the absence of priming, no significant changes in ALP activity after 5 days of ES were seen. ALP activity is considered as an early osteogenic marker. ${ }^{56}$ The substantially higher ALP activity of the stimulated group when MSCs were primed for 5 days may be explained by a synergistic effect of chemical and electrical stimulus. This is in accordance with previous results, where MSCs have been reported to require chemical osteogenic induction in order to efficiently respond to ES. ${ }^{57-58}$

\section{Conclusions}

In this paper, we demonstrated the preparation of graphene biocomposites with different graphene concentrations using a UV-crosslinkable PTMC matrix. The microscopic analysis showed homogeneous dispersion of graphene nanosheets in the polymer matrix without 
hindering the UV penetration as evidenced by the characterization results. Furthermore, low loadings of graphene at or below 3 wt.\% resulted in significant enhancements in mechanical properties and conductivity of the polymer. The composites retained the inherent processability of the polymer and could be extrusion printed into multi-layered 3D scaffolds. MSC cells showed good attachment and viability on PTMC-CCG films and scaffolds similar to that on standard PS culture plates and the graphene-PTMC composites were therefore suitable substrates for studying the effects of electrical stimulation of MSCs. The increase in ALP and col I gene expression and ALP activity suggest that ES can have an upregulating effect on osteogenic markers, and the timing of biochemical and electrical induction is crucial for obtaining upregulation. Longer osteogenic induction of MSCs before ES may have triggered a stronger response to ES. However, it needs to be noted that ES experiments were performed with cells from different donors which may have contributed to the variation in the results. The PTMC-CCG composites with enhanced thermal, mechanical and electrical properties at low graphene contents are promising materials for biomedical applications, particularly for developing novel conducting scaffolds for tissue engineering.

\section{ASSOCIATED CONTENT}

\section{Supporting Information}

Details for DSC results and rheological behaviour of PTMC samples, electrical performance of the electrical stimulation set up and cell number test. The Supporting Information is available free of charge on the ACS Publications website

\section{AUTHOR INFORMATION}

\section{Corresponding Author}

*E-mail: gwallace@uow.edu.au

\section{Acknowledgements}

Funding from the Australian Research Council Centre of Excellence Scheme (Project Number CE 140100012) is gratefully acknowledged. We acknowledge the Australian National 
Fabrication Facility (ANFF) - Materials node for providing both materials and instrumentation. We thank Cody Wright and Elise Stewart for helpful scientific discussion and Ali Jeiranikhameneh for valuable assistance with 3D printing. We thank Anna-Maija Honkala, Miia Juntunen, Sari Kalliokoski, and Sue Ku for technical assistance in cell culture. We acknowledge the use of the UOW Electron Microscopy Centre (EMC) facilities.

\section{References}

(1) Griffin, M.; Bayat, A., Electrical Stimulation inn Bone Healing: Critical Analysis by Evaluating Levels of Evidence. Eplasty 2011, 11, 303-353.

(2) Markx, G. H., The Use of Electric Fields in Tissue Engineering: A Review. Organogenesis 2008, 4 (1), 11-17.

(3) Balint, R.; Cassidy, N. J.; Cartmell, S. H., Electrical Stimulation: a Novel Tool for Tissue Engineering. Tissue Eng., Part B 2013, 19 (1), 48-57.

(4) Loh, K. P.; Bao, Q. L.; Ang, P. K.; Yang, J. X., The Chemistry of Graphene. J. Mater. Chem 2010, 20 (12), 2277-2289.

(5) Rao, C. N. R.; Biswas, K.; Subrahmanyam, K. S.; Govindaraj, A., Graphene, the New Nanocarbon. J. Mater. Chem 2009, 19 (17), 2457-2469.

(6) Dubey, N.; Bentini, R.; Islam, I.; Cao, T.; Castro Neto, A. H.; Rosa, V., Graphene: A Versatile Carbon-Based Material for Bone Tissue Engineering. Stem Cells Int 2015, 2015.

(7) Thompson, B. C.; Murray, E.; Wallace, G. G., Graphite Oxide to Graphene. Biomaterials to Bionics. Adv. Mater 2015, 27 (46), 7563-7582.

(8) Depan, D.; Girase, B.; Shah, J. S.; Misra, R. D. K., Structure-Process-Property Relationship of the Polar Graphene Oxide-Mediated Cellular Response and Stimulated Growth of Osteoblasts on Hybrid Chitosan Network Structure Nanocomposite Scaffolds. Acta Biomater 2011, 7 (9), 3432-3445.

(9) Kim, J.; Choi, K. S.; Kim, Y.; Lim, K.-T.; Seonwoo, H.; Park, Y.; Kim, D.-H.; Choung, P.-H.; Cho, C.-S.; Kim, S. Y.; Choung, Y.-H.; Chung, J. H., Bioactive Effects of Graphene Oxide Cell Culture Substratum on Structure and Function of Human AdiposeDerived Stem Cells. J. Biomed. Mater. Res. A 2013, 101 (12), 3520-3530.

(10) Ryu, S.; Kim, B.-S., Culture of Neural Cells and Stem Cells on Graphene. Tissue Eng. Regener. Med 2013, 10 (2), 39-46.

(11) Chen, G. Y.; Pang, D. W. P.; Hwang, S. M.; Tuan, H. Y.; Hu, Y. C., A Graphene-Based Platform for Induced Pluripotent Stem Cells Culture and Differentiation. Biomaterials 2012, 33 (2), 418-427.

(12) Kalbacova, M.; Broz, A.; Kong, J.; Kalbac, M., Graphene Substrates Promote Adherence of Human Osteoblasts and Mesenchymal Stromal Cells. Carbon 2010, 48 (15), 43234329.

(13) Sayyar, S.; Cornock, R.; Murray, E.; Beirne, S.; Officer, D. L.; Wallace, G. G., Extrusion Printed Graphene/Polycaprolactone Composites for Tissue Engineering. Mater. Sci. Forum 2013, 773 - 774, 496-502.

(14) Sayyar, S.; Murray, E.; Thompson, B. C.; Gambhir, S.; Officer, D. L.; Wallace, G. G., Covalently Linked Biocompatible Graphene/Polycaprolactone Composites for Tissue Engineering. Carbon 2013, 52, 296-304. 
(15) Sayyar, S.; Murray, E.; Thompson, B. C.; Chung, J.; Officer, D. L.; Gambhir, S.; Spinks, G. M.; Wallace, G. G., Processable Conducting Graphene/Chitosan Hydrogels for Tissue Engineering. J. Mater. Chem, B 2015, 3 (3), 481-490.

(16) Murray, E.; Sayyar, S.; Thompson, B. C.; Gorkin III, R.; Officer, D. L.; Wallace, G. G., A Bio-Friendly, Green Route to Processable, Biocompatible Graphene/Polymer Composites. RSC Adv 2015, 5 (56), 45284-45290.

(17) Valapa, R. B.; Pugazhenthi, G.; Katiyar, V., Effect of Graphene Content on the Properties of Poly(Lactic Acid) Nanocomposites. RSC Adv 2015, 5 (36), 28410-28423.

(18) Park, J. J.; Yu, E. J.; Lee, W.-K.; Ha, C.-S., Mechanical Properties and Degradation Studies of Poly(D,L-lactide-co-glycolide) 50:50/Graphene Oxide Nanocomposite Films. Polymer. Adv. Tech 2014, 25 (1), 48-54.

(19) Sayyar, S.; Murray, E.; Gambhir, S.; Spinks, G.; Wallace, G. G.; Officer, D. L., Synthesis and Characterization of Covalently Linked Graphene/Chitosan Composites. JOM 2015, $1-7$.

(20) Jain, S.; Sharma, A.; Basu, B., Vertical Electric Field Stimulated Neural Cell Functionality on Porous Amorphous Carbon Electrodes. Biomaterials 2013, 34 (37), 9252-9263.

(21)Li, N.; Zhang, Q.; Gao, S.; Song, Q.; Huang, R.; Wang, L.; Liu, L.; Dai, J.; Tang, M.; Cheng, G., Three-Dimensional Graphene Foam as a Biocompatible and Conductive Scaffold for Neural Stem Cells. Sci. Rep 2013, 3.

(22) Yang, K.; Wan, J.; Zhang, S.; Zhang, Y.; Lee, S. T.; Liu, Z., In Vivo Pharmacokinetics, Long-Term Biodistribution, and Toxicology of Pegylated Graphene in Mice. ACS nano 2011, 5 (1), 516-22.

(23) Xing, W. L.; Lalwani, G.; Rusakova, I.; Sitharaman, B., Degradation of Graphene by Hydrogen Peroxide. Part. Part. Syst. Charact 2014, 31 (7), 745-750.

(24) Pinto, A. M.; Moreira, S.; Goncalves, I. C.; Gama, F. M.; Mendes, A. M.; Magalhaes, F. D., Biocompatibility of Poly(lactic acid) with Incorporated Graphene-Based Materials. Colloids Surf., B 2013, 104, 229-238.

(25) Periasamy, V. S.; Athinarayanan, J.; Alfawaz, M. A.; Alshatwi, A. A., Carbon Nanoparticle Induced Cytotoxicity in Human Mesenchymal Stem Cells through Upregulation of TNF3, NFKBIA And BCL2L1 Genes. Chemosphere 2016, 144, 275284.

(26)Zhang, Y.; Ali, S. F.; Dervishi, E.; Xu, Y.; Li, Z.; Casciano, D.; Biris, A. S., Cytotoxicity Effects of Graphene and Single-Wall Carbon Nanotubes in Neural PhaeochromocytomaDerived PC12 Cells. ACS nano 2010, 4 (6), 3181-3186.

(27) Oberdorster, G.; Oberdorster, E.; Oberdorster, J., Nanotoxicology: an Emerging Discipline Evolving from Studies of Ultrafine Particles. Environ. Health Perspect 2005, 113 (7), 823-839.

(28)Zhu, K. J.; Hendren, R. W.; Jensen, K.; Pitt, C. G., Synthesis, Properties, and Biodegradation of Poly(1,3-Trimethylene Carbonate). Macromolecules 1991, 24 (8), 1736-1740.

(29) Bat, E.; Kothman, B. H. M.; Higuera, G. A.; van Blitterswijk, C. A.; Feijen, J.; Grijpma, D. W., Ultraviolet Light Crosslinking of Poly(Trimethylene Carbonate) for Elastomeric Tissue Engineering Scaffolds. Biomaterials 2010, 31 (33), 8696-8705.

(30)Zhang, Z.; Kuijer, R.; Bulstra, S. K.; Grijpma, D. W.; Feijen, J., The In Vivo and In Vitro Degradation Behavior of Poly(Trimethylene Carbonate). Biomaterials 2006, 27 (9), 1741-1748.

(31) Schüller-Ravoo, S.; Feijen, J.; Grijpma, D. W., Flexible, Elastic and Tear-Resistant Networks Prepared by Photo-Crosslinking Poly(Trimethylene Carbonate) Macromers. Acta. Biomater 2012, 8 (10), 3576-3585. 
(32) Hummers, W. S.; Offeman, R. E., Preparation of Graphitic Oxide. J. Am. Chem. Soc 1958, 80 (6), 1339-1339.

(33) Kovtyukhova, N. I.; Ollivier, P. J.; Martin, B. R.; Mallouk, T. E.; Chizhik, S. A.; Buzaneva, E. V.; Gorchinskiy, A. D., Layer-by-Layer Assembly of Ultrathin Composite Films from Micron-Sized Graphite Oxide Sheets and Polycations. Chem. Mater 1999, 11 (3), 771-778.

(34)Li, D.; Muller, M. B.; Gilje, S.; Kaner, R. B.; Wallace, G. G., Processable Aqueous Dispersions of Graphene Nanosheets. Nat. Nanotechnol 2008, 3 (2), 101-105.

(35) Gambhir, S.; Murray, E.; Sayyar, S.; Wallace, G. G.; Officer, D. L., Anhydrous Organic Dispersions of Highly Reduced Chemically Converted Graphene. Carbon 2014, 76, 368377.

(36) Niemela, S. M.; Miettinen, S.; Konttinen, Y.; Waris, T.; Kellomaki, M.; Ashammakhi, N. A.; Ylikomi, T., Fat Tissue: Views on Reconstruction and Exploitation. J. Craniofac. Surg 2007, 18 (2), 325-35.

(37) Björninen, M.; Siljander, A.; Pelto, J.; Hyttinen, J.; Kellomäki, M.; Miettinen, S.; Seppänen, R.; Haimi, S., Comparison of Chondroitin Sulfate and Hyaluronic Acid Doped Conductive Polypyrrole Films for Adipose Stem Cells. Ann. Biomed. Eng 2014, 42 (9), 1889-1900.

(38) Gimble, J.; Guilak, F., Adipose-Derived Adult Stem Cells: Isolation, Characterization, and Differentiation Potential. Cytotherapy 2003, 5 (5), 362-369.

(39) Dominici, M.; Le Blanc, K.; Mueller, I.; Slaper-Cortenbach, I.; Marini, F.; Krause, D.; Deans, R.; Keating, A.; Prockop, D.; Horwitz, E., Minimal Criteria for Defining Multipotent Mesenchymal Stromal Cells. The International Society for Cellular Therapy Position Statement. Cytotherapy 2006, 8 (4), 315-317.

(40) Pelto, J.; Bjorninen, M.; Palli, A.; Talvitie, E.; Hyttinen, J.; Mannerstrom, B.; Suuronen Seppanen, R.; Kellomaki, M.; Miettinen, S.; Haimi, S., Novel Polypyrrole-Coated Polylactide Scaffolds Enhance Adipose Stem Cell Proliferation and Early Osteogenic Differentiation. Tissue Eng., Part A 2013, 19 (7-8), 882-892.

(41) Kronsteiner, B.; Wolbank, S.; Peterbauer, A.; Hackl, C.; Redl, H.; van Griensven, M.; Gabriel, C., Human Mesenchymal Stem Cells from Adipose Tissue and Amnion Influence T-Cells Depending on Stimulation Method and Presence of other Immune Cells. Stem Cells Dev 2011, 20 (12), 2115-2126.

(42)Lee, H. J.; Choi, B. H.; Min, B. H.; Park, S. R., Changes in Surface Markers of Human Mesenchymal Stem Cells During the Chondrogenic Differentiation and Dedifferentiation Processes In Vitro. Arthritis. Rheum 2009, 60 (8), 2325-2332.

(43)Lindroos, B.; Boucher, S.; Chase, L.; Kuokkanen, H.; Huhtala, H.; Haataja, R.; Vemuri, M.; Suuronen, R.; Miettinen, S., Serum-Free, Xeno-Free Culture Media Maintain the Proliferation Rate and Multipotentiality of Adipose Stem Cells In Vitro. Cytotherapy 2009, 11 (7), 958-972.

(44) Kocaoemer, A.; Kern, S.; Kluter, H.; Bieback, K., Human AB Serum and ThrombinActivated Platelet-Rich Plasma are Suitable Alternatives to Fetal Calf Serum for the Expansion of Mesenchymal Stem Cells from Adipose Tissue. Stem. cells 2007, 25 (5), 1270-1278.

(45) Parker, A.; Shang, H.; Khurgel, M.; Katz, A., Low Serum and Serum-Free Culture of Multipotential Human Adipose Stem Cells. Cytotherapy 2007, 9 (7), 637-646.

(46) Pfaffl, M. W., A New Mathematical Model for Relative Quantification in Real-Time RTPCR. Nucleic. Acids. Res 2001, 29 (9), e45.

(47) Hardy, J. G.; Geissler, S. A.; Aguilar, D., Jr.; Villancio-Wolter, M. K.; Mouser, D. J.; Sukhavasi, R. C.; Cornelison, R. C.; Tien, L. W.; Preda, R. C.; Hayden, R. S.; Chow, J. K.; Nguy, L.; Kaplan, D. L.; Schmidt, C. E., Instructive Conductive 3D Silk Foam-Based 
Bone Tissue Scaffolds Enable Electrical Stimulation of Stem Cells for Enhanced Osteogenic Differentiation. Macromol. Biosci 2015, 15 (11), 1490-1496.

(48) Hu, W.-W.; Hsu, Y.-T.; Cheng, Y.-C.; Li, C.; Ruaan, R.-C.; Chien, C.-C.; Chung, C.-A.; Tsao, C.-W., Electrical Stimulation to Promote Osteogenesis using Conductive Polypyrrole Films. Mater. Sci. Eng. C 2014, 37, 28-36.

(49) John, A. A.; Subramanian, A. P.; Vellayappan, M. V.; Balaji, A.; Mohandas, H.; Jaganathan, S. K., Carbon Nanotubes and Graphene as Emerging Candidates in Neuroregeneration and Neurodrug Delivery. Int. J. Nanomed 2015, 10, 4267-4277.

(50) Murray, E.; Thompson, B. C.; Sayyar, S.; Wallace, G. G., Enzymatic Degradation of Graphene/Polycaprolactone Materials for Tissue Engineering. Polym. Degrad. Stab 2015, $111,71-77$.

(51)Pimenta, M. A.; Dresselhaus, G.; Dresselhaus, M. S.; Cancado, L. G.; Jorio, A.; Saito, R., Studying Disorder in Graphite-Based Systems by Raman Spectroscopy. Phys. Chem. Chem. Phys 2007, 9 (11), 1276-1291.

(52) Hasin, P.; Alpuche-Aviles, M. A.; Wu, Y., Electrocatalytic Activity of Graphene Multilayers toward I-/I3-: Effect of Preparation Conditions and Polyelectrolyte Modification. J. Phys. Chem. C 2010, 114 (37), 15857-15861.

(53) Gabriel, C.; Peyman, A.; Grant, E. H., Electrical Conductivity of Tissue at Frequencies below 1 Mhz. Phys. Med. Biol 2009, 54 (16), 4863-4878.

(54) Hammerick, K. E.; James, A. W.; Huang, Z.; Prinz, F. B.; Longaker, M. T., Pulsed Direct Current Electric Fields Enhance Osteogenesis in Adipose-Derived Stromal Cells. Tissue Eng., Part A 2010, 16 (3), 917-931.

(55) Creecy, C. M.; O'Neill, C. F.; Arulanandam, B. P.; Sylvia, V. L.; Navara, C. S.; Bizios, R., Mesenchymal Stem Cell Osteodifferentiation in Response to Alternating Electric Current. Tissue Eng., Part A 2013, 19 (3-4), 467-474.

(56) Štefková, K.; Procházková, J.; Pacherník, J., Alkaline Phosphatase in Stem Cells. Stem Cells Int. 2015, 2015, 11.

(57) Kim, I. S.; Song, J. K.; Song, Y. M.; Cho, T. H.; Lee, T. H.; Lim, S. S.; Kim, S. J.; Hwang, S. J., Novel Effect of Biphasic Electric Current on In Vitro Osteogenesis and Cytokine Production in Human Mesenchymal Stromal Cells. Tissue Eng., Part A 2009, 15 (9), 2411-2422.

(58) Hess, R.; Jaeschke, A.; Neubert, H.; Hintze, V.; Moeller, S.; Schnabelrauch, M.; Wiesmann, H.-P.; Hart, D. A.; Scharnweber, D., Synergistic Effect of Defined Artificial Extracellular Matrices and Pulsed Electric Fields on Osteogenic Differentiation of Human MSCs. Biomaterials 2012, 33 (35), 8975-8985. 
Table of contents graphics

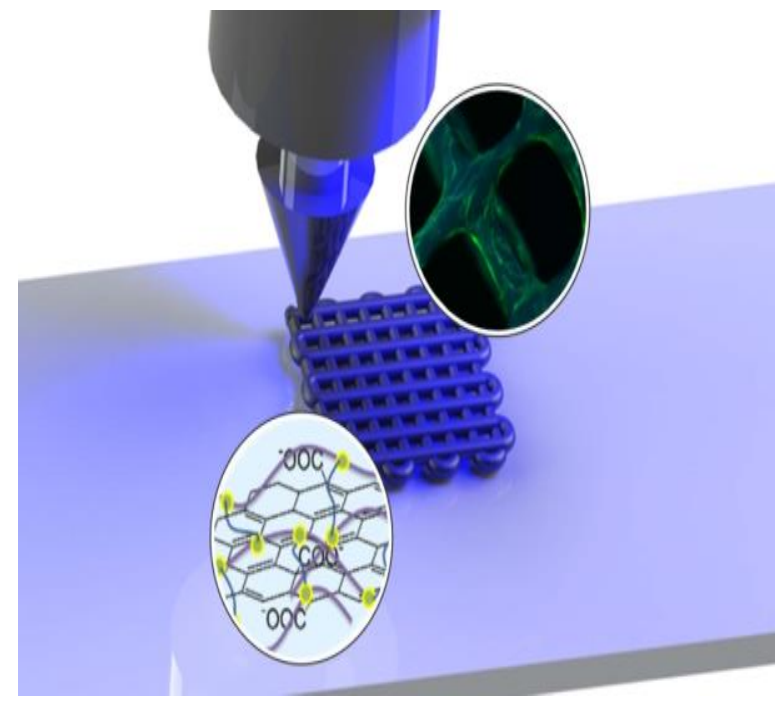

